DIMENSI, VOL. 8, NO. $2: 317-328$

JULI 2019

ISSN: 2085-9996

\title{
THE INFLUENCE OF VISUALIZATION STRATEGY ON \\ READING COMPREHENSION ABILITY
}

\author{
Musdizal $^{1}$ \\ English Education Program, Faculty of Education And Teacher Training, State Islamic Intitute of Kerinci, \\ Indonesia \\ mudizal@yahoo.com
}

\begin{abstract}
The objective of thisresearch was to know the effect of using Visualization Strategy in teaching recount text on reading comprehensionability at the second grade students of SMPN 4 Kerinci. Then, the type of the researchwas quasi experimental research. Besides, the population of the research was the second grade students of SMPN 4 Kerinci, it was 75 students. Moreover, the sample of this research consisted of 50 students from two classes. There were experiment class and control class. The analysis of data used t-test. The result of the research showedthat there was significance effect of using Visualization strategy toward students' reading comprehension of recount text. It could be seen of hypothesis was gotten the mean of control class was 60 and the standard deviation was 102 while the experimental class was 67,8 and standard deviation was 118,16. And after doing ttest, it was found that $t_{\text {observe }}=2,6>t_{\text {table }}=1,68$. It can be summarized that there was the significant effect of using visualization strategy in the students' reading comprehension achievement of recount text.
\end{abstract}

Keywords: Visualization Strategy; Recount Text; Reading Comprehension

\section{INTRODUCTION}

Reading is very important for some purposes, such as for entertainment, for education and for getting information. Harmer (1998) states that"reading is the way in which people extract meaning from the text." For English as a Foreign Language students, reading is one of the language skills which should be developed in learning English. Mikulecky and Jeffries in Yuliani (2013)define that "the reasons for the importance of reading are; by reading the students can increase their acquisition in the target language, reading also can make the students more comfortable with written English, and finally, the students can get new vocabulary, knowledge, idea, and information from the text." In short, reading is very essential for EFL students to improve their language comprehension skill as well as their knowledge.

Because of the importance of reading comprehension skill, students of Junior High School have to be able to understand the meaning of a short functional written text. According to the English syllabus of Junior High School, there are three kinds of texts which should be 
understood by the second grades students, there are descriptive, narrative and recount text. In summary, reading comprehension skill is really important for EFL students to comprehend every text they read.

However, reading comprehension skill is not easy for English as a Foreign Language students. According to Pang, et al, (2003)“there are some aspects that affect students' comprehension; the first is prior knowledge, the second is knowledge of the world, the third is cultural knowledge, the fourth is subject-matter knowledge and the last is linguistic knowledge." In conclusion, reading is difficult for EFL students. Because they have to comprehend all of the linguistics aspect, such as some new words and structure which are completely different from their native language.

Moreover, there are some facts that indicate the reading ability of Indonesian students is still low. The survey was done by many programmes, included national and international survey. Some of them are PIRLS, PISA, and UN. Firstly, Mullis, et al, (2012) notes "PIRLS (Progress in International Reading Literacy Study), an international survey of reading comprehension that has been conducted every five years since 2001, reported that in 2011 Indonesia was at rank 44 out of 45 countries around the world that participated." Secondly, According to Gurria (2018) "PISA (Programme for International Student Assessment), an ongoing programme that offers insight into education policy and practice. Which focused on science, reading, and mathematics, reported that in 2015 reading assessment result of Indonesia was at rank 64 out of 70 participants, with the mean score was 397 where the average score was 493." This means that the Indonesian students' reading ability is bellow of the average. Lastly, UN (Ujian Nasional), the final examination for the Indonesian Students to Graduate from their Elementary school or high school; one of the skills that are tested is reading. Revealed that nationally in 2017 the mean score of students' achievement in English Subject was 50,18. Based on the facts above, it can be concluded that students' reading comprehension skill is still low nationally and internationally. It can be indicated that it is very important to find a way to improve students' reading comprehension skill.

Besides, based on the preliminary observation at SMP 4 Kerinci, the researcher interviewed an English teacher and some students. The English teacher explained that the 
students still had problems in reading comprehension skill. Most of them were lack of vocabulary that make them got difficulties in comprehend the text and difficulties to identifiying the main idea, details information, and sequence of the text. Based on those problems it impact to students got low score in reading comprehension. Besides, the researcher also has interviewed some students related to their difficulty in reading comprehension. It found that the students got much difficulties and bored in lerning reading, because they do not use any reading strategy effectively to gain information from the text. It can be concluded that English is a difficult subject for Junior High School 4 Kerinci students. Because they have to consider about aspects of English language and use the reading strategy effectively.

There are some factors which can influence students' reading comprehension achievement, one of them is applying an appropriate teaching strategy. Rowe (2005) states that"teaching strategy is helpful for effective teaching practice." The correct method use is very important, that the students can understand the lesson easily and rapidly. The goal of the teaching will be achieved. In addition, the use of interesting teaching strategies can improve students' enthusiasm and motivation to learn English.

Specifically, visualization strategy is appropriate to improve students reading comprehension achievement. Stephanie Harvey and Anne Goudvis (2000) say that"visualization is being read by drawing and speculate what may happen in our mind, to help students develop their ability." In visualization strategy, students have to make sense with the text by drawing in their mind. It can make the students focus on the text that they read. And also it can develop students' motivation and interest to read the text by speculating what may be happening with the characters in the text. Then, the students share they visualize with their friends, it will increase students' vocabulary mastery. In summary, the teacher can determine whether the students truly understand the text or not. Additionally, the researcher found some studies related to the use of visualization strategy in teaching reading. The research was conducted by; Loh Pack Swan (2008), Widi Astani (2001), and Wisnu Adi Wicaksono (2016), they found that the implementation of visualization strategy is effective in improving students' reading comprehension achievement. 
Goudvis and Harvey in Nelson (2005) suggest that "the use of gradual releases of responsibility in which consist of three steps. Those are; Teacher Models, Guided Practice, and Independent Practice. Based on the format from Goudvis and Harvey, McLaughlin in Nelson designs the steps of Draw and Label Visualizations with implementing of a process of gradual release responsibility those steps are described as follows."

1) Teacher Models

a) The teacher demonstrates (model) the strategy by using a reading title and first paragraph to the students.

b) Then, the teacher sketches what she sees in her mind and labels the pictures. The teacher reminds the students that sketches are acceptable. The teacher also makes the simple sketch for them.

c) The teacher continues reading more paragraphs and again sketches what is visualized and labels it.

2) Guided Practice

a) It begins with the teacher reading aloud a view more pages, stopping at points of interest.

b) The teacher asks the students to visualize and creates pictures in their mind

c) The teacher encourages students to discuss their visualization and helps students sketch their visions on paper.

d) After the students finish sketching their own vision, the teacher thinks aloud and makes the teacher's sketch.

e) The students share their sketches with their partner and the teacher points out individual differences.

3) Independent Practice

a) This level starts with the teacher continuing to read aloud the text while the students draw and label their own visualization.

b) When complete, the students share the final product and discuss the story/ text.

c) The students are encouraged to reflect their sketch in improving their understanding. 
To conclude, in doing visualization strategy in order to improve students' reading comprehension of recount text, this research only concerned with comprehend the meaning of the text that they read. Recount is a text which retells events or experiences in the past time. Its purpose is either to inform or to entertain the audience. It also has generic structures, there are orientation, event, and reorientation. And use language features the most specific one is use past tense.

Recount text is one of the texts that have to be learned by students in junior high school level based on syllabus curriculum (2013). According Knapp and Watkins (2007)'Recount text is kind of text retelling of an incident, action or events that have occured in the past." Anderson in Malinda (2007) states that"recount text is a text that tells about something that happened or retells past events or activities and has a purpose to give detailed information about what and when of that events."

Artono Wadirman (2008) "recount text is a text that telling the reader about one story, action or activity. Its goal is to entertain or informing the reader." Furthermore, recount text is a kind of text that retelling about an action or event that have done in the past time. And the purpose of recount text just gives information or entertainment for the reader or listener. In recount text, it has a generic structure and language features. The generic structures of the recount text are orientation, event, and reorientation. The explanations are as follow:

Orientation : Tells who was involved, what happened, where the event took place, and when it happened.

Event tells : What happened and in what sequence.

Reorientation : Consist of optional-closure of events or ending.

Furthermore, Pang (2003) states that "reading comprehension is about understanding written texts. It is a complex activity that involves both perception and though. Reading comprehension consist of two related processes, there are word recognition and comprehension." The first is word recognition refers to the process of perceiving how written symbols correspond to one's spoken language. In addition, comprehension is the process of making sense of word, sentences and connected text. Here, the readers typically make use of background knowledge, vocabulary, grammatical knowledge, experience with text and other 
strategies in order to help them understand written text. In conclusion, when the students read a text, they have to do two actions at the same time, there are perceptions and though. They use their perception while recognizing the words, and use their though when comprehending the text.

Pang (2003) also states that "Reading is a skill that will empower everyone who learns it. They will be able to get benefit from the store of knowledge in printed materials an ultimately, to contribute to that knowledge." finally, from two experts' state above, it can be concluded that reading is a skill to a process of decoding all units in the text to get the knowledge.

Besides, reading is thinking, understanding and getting at the meaning behind the text. Geoffrey (2003) states that "reading skill was pointed out that reading involves correlating elements of language with meaning." In addition, by reading students can involves and get more knowledge from the text that they read. And by correlating the elements of language with meaning, they can understand the text well and comprehend it.

Reading comprehension is an important skill. As we know, reading comprehension is more than a single skill. It involves the coordination of the range of abilities and strategy. Harmer (2003)say that "reading comprehension is useful for language acquisition." Reading definitely will improve student's knowledge because the more they read, the more they get knowledge. Reading also has a positive effect on students' vocabulary knowledge, on their spelling or their writing. To comprehend a text, students have to focus on what they read, because reading not only reading but also comprehending the text systematically. Harmer also states that reading is a process of interpreting the message. These statements show that without understanding the word, students cannot know what the meaning of the text is.

\section{METHODOLOGY}

This research was a quasi-experimental research.arikunto (2005) says that "experimental research is aimed at knowing whether the effect or not of "something" which is experimented to the subject of the research." since it is not possibly to control and manipulate all relevant variables so this research used the method of quasi-experiment. 
Furthermore, the population of this research was the student of grade VIII. They were 75 persons who are distributed into three classes. From those three classes class B and C were selected as the sample of the research by using the ClusterRandom Sampling Technique. The result is class B as experiment class consists of 25 students and class C as control class are 25 students.

In order to collect the data, the instruments which used in this research were test. The test were pre-test and post-test. The purpose of giving a pre-test was to know the students' reading comprehension in recount text before this research. And the purpose of giving a posttest was to know the students' reading comprehension after the treatment. Before using the instrument it had been validated by expert and also tried out to students of class A which had been selected as trying out class.

The data analyzed by using statistical. Before testing the hypothesis, the data should be analyzed by using pre-requisite analysis, that is, test of normality and homogeneity. The test ofnormality used Shapiro-Wilk Test and the homogeneity testing by Variance test (F-test). While the test of hypothesis was done by usingt-test.

\section{RESULT/FINDINGS}

\section{The Description of the Data}

\section{a. The Pre-Test Result of Experimental and Control Class}

Table. 1. The pre-test Result of Experimental and Control Class

\begin{tabular}{|l|c|c|}
\hline \multicolumn{1}{|c|}{ Class } & Experiment & Control \\
\hline $\mathrm{N}$ & 25 & 25 \\
\hline Maximum Score & 80 & 85 \\
\hline Minimum Score & 40 & 40 \\
\hline Mean & 55 & 60 \\
\hline
\end{tabular}

The pre-test conducted to ensure that the students have the same background and the same English proficiency. The table above showed that the highest score of reading comprehension of recount text before getting the treatment in experiment class was 85, 
while the lowest score was 40, the average score was 55,5. Itsame, in the control classthe highest score was 80, the lowest score was 40, the average score was 55 .

\section{b. The Post-Test Result of Experimental and Control Class}

Table.2. The post-test Result of Experimental and Control Class

\begin{tabular}{|l|c|c|}
\hline Class & Experiment & Control \\
\hline $\mathrm{N}$ & 25 & 25 \\
\hline Maximum Score & 90 & 85 \\
\hline Minimum Score & 50 & 40 \\
\hline Mean & 67 & 60 \\
\hline
\end{tabular}

After the researcher gave the treatment, the researcher gave post-test to the students in experimental and control class to find out the result of the whole treatment. The table above showed that the highest score of reading comprehension of recount text after getting the treatment by using visualization stategyin experiment class was 90 , while the lowest score was 50, the average score was 67. Itcontras, in the control classwhich used conventional strategy that the highest score was 85 , the lowest score was 40 , the average score was 60 .

\section{c. The Result of Hypothesis Testing}

Table.3. The Result of Hyphothesis

\begin{tabular}{|c|c|c|}
\hline \multirow{2}{*}{ Classification } & \multicolumn{2}{|c|}{ Class } \\
\cline { 2 - 3 } & Experiment & Control \\
\hline $\mathbf{N}$ & 25 & 25 \\
\hline$\overline{\boldsymbol{x}}$ & 67 & 60 \\
\hline $\boldsymbol{S}^{\mathbf{2}}$ & 118 & 102 \\
\hline $\boldsymbol{S}$ & 10,9 & 10,09 \\
\hline $\boldsymbol{t}_{\text {score }}$ & & 2,6 \\
\hline $\boldsymbol{t}_{\text {table }}$ & & \\
\hline
\end{tabular}


The table above shows that in test of hypothesis test, the result was: mean score of experimental class was 67. In control class was 60. So it means students' reading comprehension of recount text in experimental class got higher score rather than in control class.

Then, the T-score was 2,6 while T-table was 1,67 with $\alpha=0,05$. Since T-score was bigger than T-table (Ts $>\mathrm{Tt}$ ) so hypothesis Ha was accepted. It can be concluded that students' reading comprehension of recount text which was taught through visualization strategy was better than students' reading comprehension of recount text wich was taught through conventional strategy.

\section{Discussions}

Based on the statistical analysis of the data obtained, the researcher would like to interpret and discuss the result. The researcher did this research in SMPN 4 Kerinci, where the students' the second grade as population and the sample of this research was VIIIB as experimental class and VIIIC as control class. In this result, the researcher tried to used Visualization Strategy as a strategy in teaching reading comprehension of racount text.Thereore, that strategy would be easy to apply in teaching and learning process, especially in reading.

Before using Visualization Strategy the maxsimum score of the students in experiemental class was 80 and the minimum score was 40 . While after using the Visualization Strategy the maxsimum score was 90 and the minimum score was 50. It's means, the students' score have more improvement. It can concluded that the score in after using Visualization Strategy was higher than before using Visualization Strategy or the learning result of teaching reading by using Visualization Strategy was better than conventional method. In addition, the researcher found the students in experiemental class were more active than the students in the control class that teaching and learning reading whithout using Visualization Strategy.

Then hypothesis with $5 \%(0,05)$ of level significant and the value of $t_{\text {table }}$ of the level freedom df (48). The value t-count $(2,6)$ was higher then value of t-table $(1,67)$. It 
had mention that $t_{\text {observe }}$ in this research was higher than the value of the $t_{\text {table. It meant that }}$ $\mathrm{H}_{\mathrm{a}}$ was accepted and $\mathrm{H}_{\mathrm{o}}$ was rejected. In other word, there was signifficant effect of using Visualization Strategy in teaching recount text on students' reading comprehension at the second grade of SMPN 4 Kerinci in academic year 2018/2019.

Moreover, after conducted this research, the researcher found some previous researches that use Visualization Strategy, those researches found Visualization Strategy also had significant effect in learning English. Besides, it would support of the researcher's research result in used Visualization Strategy. First, the researcher found the research that had conducted by Loh Pack Swan, which indicated that the students have positive perceptions of the use of visualization strategy in reading an expository text. In overall terms, the findings seem to indicate the flexibility of using visualization strategy as a tool to improve the reading comprehension process of reading an expository text.

Secondly, the researcher also found the research was done by Widi Astani, he stated that there was a statistically significant difference in students' reading comprehension between students taught using visualization in Desuggestopedia and those taught without visualization in conventional teaching method. Thirdly, the research had conducted by Izza Dinillah, she stated that there was a significant effect of using explicit Instruction toward students' writing ability on the descriptive text at the first year students of Boarding senior high school Daarun Nahdhah Thawalib Bangkirang. Fourthly, the research was done by Wisnu Adi Wicaksono (2016), the finding of this research showed that the students' gave a positive response to the implementation of Visualization technique in their reading activities. It means that the Visualization technique could improve the students' in reading comprehension. Fifthly, the research was done by Amnah Ahmad Nahari and Hind Abdulaziz Alfadda, which research showed that there was a significant effect of using Visualization Strategies to Improve Students' Spelling Skill.

It can be concluded that the Visualization Strategy is the strategy that effective in teaching reading. Because of the research that researcher did and the research conducted 
by other researcher indicates that the ability of students increased after using Visualization Strategy in learning English reading.

\section{CONCLUSION}

Based on the result, it can be concluded that there was significant effect of using visualization strategy toward students' reading comprehension of recount text at the eight grade of SMPN 4 Kerinci. The success of the research can be proved by the students score in reading test of post-test for both classess, as follow:

The result of post-test showed the differences result achieved by the control class which was taugh without using visualization strategy with the experimental class which was taugh by using visualization strategy. The mean of control class was 60 and the standard deviation was 10,09 while the experimental class was 67,8 and standard deviation was 10,87 . And after doing $\mathrm{t}$-test, it was found that $\mathrm{t}_{\text {observe }}=1,86>\mathrm{t}_{\text {table }}=1,68$. So there is difference students' reading score of the second grade of SMPN 4 Kerinci was taught by using visualization strategy and without using visualization strategy. The finding showed that there was the significant improvement of using visualization strategy in the students' reading comprehension of recount text.

\section{REFERENCES}

Arikunto, Suharsimi. 2014. Prosedur Penelitian. Jakarta: Rineka Cipta.

Astani, Widi. 2011. The Use of Visualization in Desuggestopedia TeachingMethod to Improve The Students' Reading Comprehension. EnglishDepartment Faculty of Languages And Arts Semarang State University.Broughton,Geoffery,et al. 2003.Teaching English as a Foreign Language. Second Edition. London and New York: Routledge.

Arini, Dunia Statistika. Retrieved on on $7^{\text {th }}$ December 2018. From: http://arini2992.blogspot.co.id/2011/04/normal-0-false-false-false-en-us-x none.htm, Arini, Dunia Statistika, accesed on $7^{\text {th }}$ December 2018.

Brown,H. Douglas. 2004. Language Assesment: Principles and ClassroomPractice. San Francisco, California: Longman.

Brown, H. Duoglas. 2000. Teaching by Principles: an Interactive Approach to Language Pedagogy. Second Edition. San Francisco: Longman 
Creswell, John W. 2012. Educational Research: Planning, Conducting andEvaluating Quantitative and Qualitative Research. Boston: Pearson.

Drs. Kuntjojo. 2009. Metodologi Penelitian. Kediri: Universitas Nusantara PGRI Kediri.

Duffy, Gerald G. 2009. Explaining Reading: A Resource For Teaching Concepts,Skills, And Strategies. $2^{\text {nd }}$ Edition.New York: The Guilford Press.

Harmer, Jeremy. 1998. How to Teach English: an Introduction to the Practice of English Language Teaching. Cambridge: Longman.

Harmer, Jeremy.The Practice of English Language Teaching.Third Edition.Cambridge, UK: Longman. 